\title{
Gunshot Wound to the Atlantoaxial Spine Associated with Vertebral Artery Occlusive Injury
}

\section{Traumatismo atlantoaxial por projétil de arma de fogo associado à lesão oclusiva da artéria vertebral}

\author{
Rogério Martins Pires de Amorim ${ }^{1,2}$ Leonardo Miguez ${ }^{1,2}$ Maristella Reis ${ }^{1,2}$ Lucas Loiola Santos ${ }^{1,2}$ \\ Francisco José Torrão Junior ${ }^{1,2}$ José Fernando Guedes-Corrêa ${ }^{1,2}$ \\ ${ }^{1}$ Division of Neurosurgery, Hospital Universitário Gaffrée e Guinle \\ (HUGG), Universidade Federal do Estado do Rio de Janeiro (UNIRIO), \\ Rio de Janeiro, Brazil \\ 2 Neurosurgical Service, Hospital Pasteur, Rio de Janeiro, Brazil \\ Arq Bras Neurocir 2016;35:157-159.

\begin{abstract}
Address for correspondence Maristella Reis da Costa Pereira, MD, Division of Neurosurgery, Hospital Universitário Gaffrée e Guinle (HUGG), Universidade Federal do Estado do Rio de Janeiro (UNIRIO), Rio de Janeiro, Brazil. Rua Jardim Botânico $n^{\circ} 700$ Sala 407-Jardim Botânico - Rio de Janeiro, RJ, Brazil - 22461-000

(e-mail: maristellareis@gmail.com).
\end{abstract}
Abstract
Keywords
- gunshot wound
- atlantoaxial spine
- vertebral artery

Atlantoaxial spine injuries due to firearm are uncommon. However, civilian gunshot wounds are becoming more frequent in modern society. The authors report a case of a middle age man with a penetrating neck gunshot wound; discuss the complexity of this type of trauma and its management.

Lesões da junção atlantoaxial por projetil de arma de fogo (PAF) são incomuns. No entanto, traumatismos por arma de fogo vem se tornando cada vez mais frequentes na população civil da sociedade moderna. Os autores apresentam um relato de caso de um homem de meia-idade com um traumatismo penetrante em região cervical por PAF, é discutida a complexidade e o manejo deste tipo de trauma.

atlantoaxial

- artéria vertebral

\section{Introduction}

Penetrating atlantoaxial spine (AAS) injuries due to gunshot wounds are uncommon. ${ }^{1-4}$ Usually, this type of lesion is fatal. In rare cases the patient survives, probably due to particularities such as low velocity of the projectile, a peculiar trajectory of the bullet not affecting the spinal cord parenchyma directly and a unilateral vascular lesion. ${ }^{1,5}$ In such cases, when the patient survives the acute phase of the injury, they may present with complete or partial neurological deficits, spine instability due to fractures and ligament rupture, and/or vascular lesions. ${ }^{1,6-8}$

We report and discuss a case of a middle age man admitted at the emergency room complaining of neck pain after a gunshot wound to the left side of his neck.

\section{Case Report}

A 56-year-old Caucasian man was admitted with a gunshot wound at the left posterior region of the neck, with the entrance site next to the mastoid eminence. The patient had no motor or sensory deficits whatsoever, and his main complaint was strong neck pain.

We performed a computed tomography (CT) scan of the cervical spine and it demonstrated a comminuted fracture of the left portion of the arch of $\mathrm{C} 1$ and the bullet embedded at the lateral mass of the atlas ( $\mathbf{- F i g}$. 1). Because of the possibility of a lesion of the vertebral artery, we performed a vascular study with a vertebral angio-CT scan that revealed an occlusion of the left vertebral artery (-Fig. 2). received

February 4, 2016

accepted

March 22, 2016

published online

May 6, 2016
DOI http://dx.doi.org/

10.1055/s-0036-1583937. ISSN 0103-5355.
Copyright $\odot 2016$ by Thieme Publicações License terms Ltda, Rio de Janeiro, Brazil 


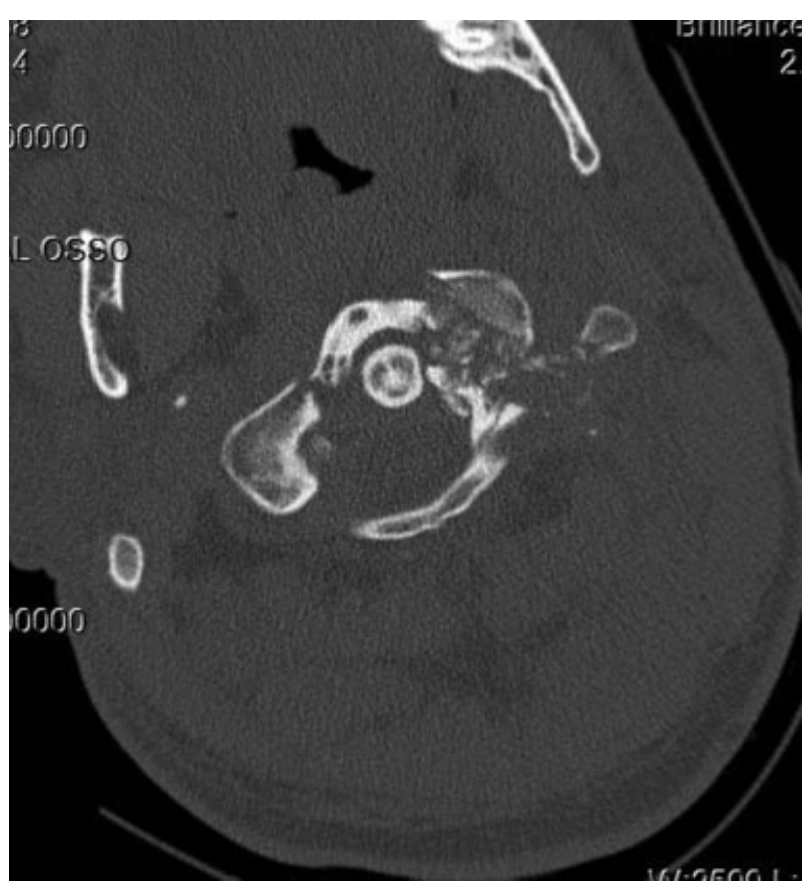

Fig. 1 Atlanto-axial CT scan showing comminuted fracture of the left portion of the $\mathrm{C} 1$ arch.

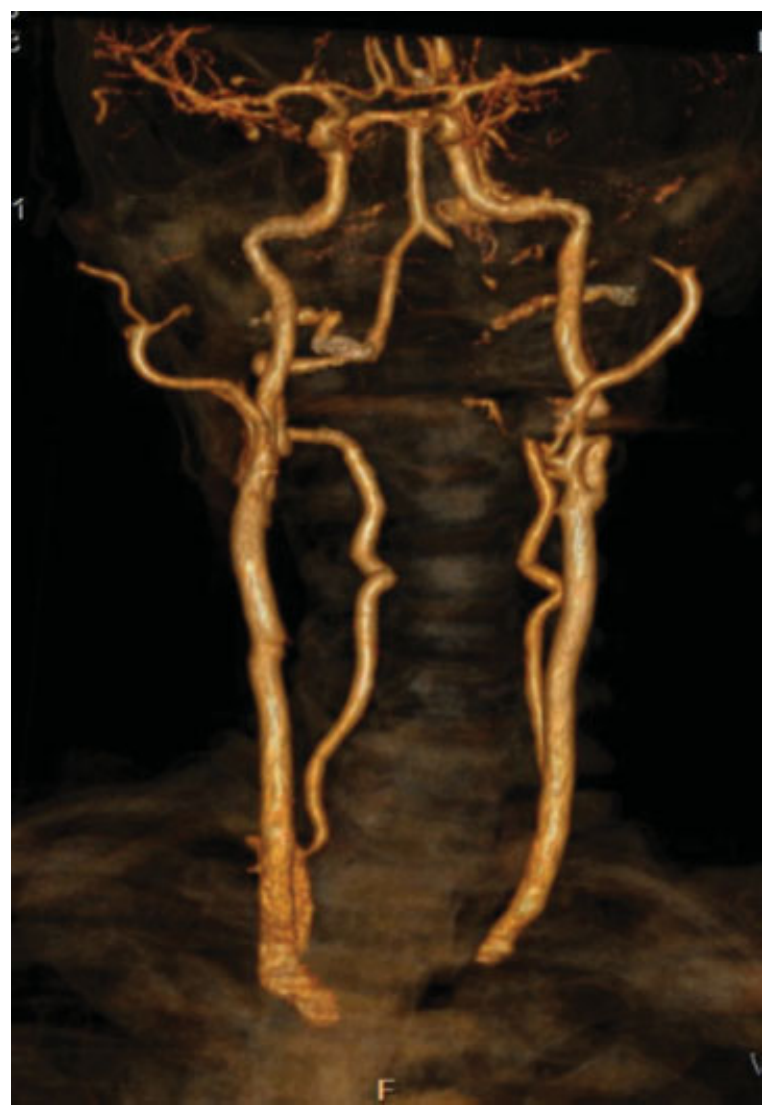

Fig. 2 Vertebral angio-CT scan revealing occlusion of the left vertebral artery.
The patient was initially maintained with a Philadelphia collar and, because of the osteoarticular lesion with disruption of the atlanto-axial joint, it was considered unstable. We then performed a cervical-occipital surgical approach to stabilize the atlanto-occipital joint.

A median incision from the external occipital protuberance to the spinous process of $\mathrm{C} 6$ gave access to the cervical spine. After the dissection of the neck muscles the instabilization of the atlanto-axial joint was evident, given that the left lateral mass of $\mathrm{C} 1$ was fracture. We also observed a dural cerebrospinal fluid fistula between the skull base and C1. It was sealed with Prolene ${ }^{\circledR}$ suture (Ethicon, New Jersey, USA) and biological glue. Considering the instabilization of $\mathrm{C} 1$ and $\mathrm{C} 2$, an occipital cervical fusion including two levels below the instable segment was the technique of choice. Transpedicular screws were then positioned at $\mathrm{C} 2, \mathrm{C} 3$, and $\mathrm{C} 4$, and the system assembled with two parallel bars fixing the transpedicular screws to the occipital bone to stabilize the system.

We made no effort to retrieve the bullet or to explore the vertebral artery given that the attempt to access the lateral mass could result in worsening of the vascular and the joint lesion.

The patient's neck pain disappeared after the procedure but the fistula remained. The patient underwent a second surgery for revision of the fistula. We also placed an external ventricular derivation to divert the cerebrospinal fluid, decreasing the fistula debt and allowing it to close properly. After a week, the fistula was resolved.

The 3-month follow-up imaging revealed a solid fusion of the atlanto-occipital junction and the patient is asymptomatic (-Fig. 3).

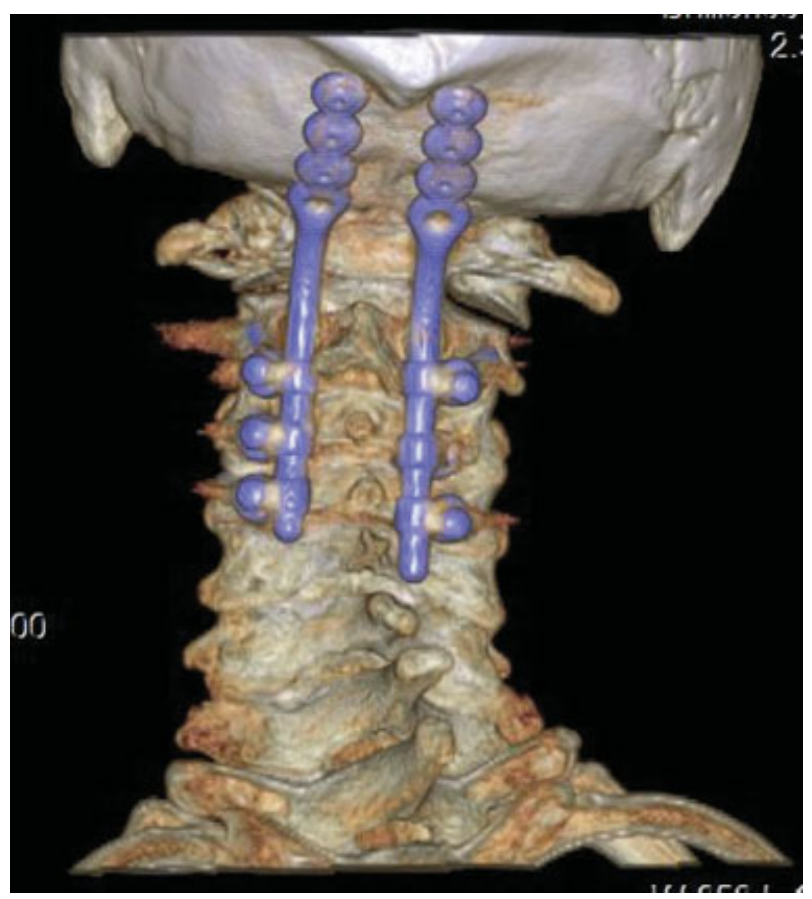

Fig. 3 Cervical CT scan reconstruction after arthrodesis. 


\section{Discussion}

There are not many cases of atlantoaxial complex penetrating trauma described in the English literature considering the high mortality of this type of wound. ${ }^{1-4}$ When the patient survives, usually it is due to a low velocity bullet combined with a peculiar trajectory dissipating the kinetic energy and heat to the paravertebral soft tissues and vertebrae, not affecting the major structures as the spinal cord and vessels. ${ }^{1,9-12}$

Careful investigation is required, given that the management of these patients will depend on the clinical presentation, the location, and damage extension to the atlantoaxial complex. Plain radiography shows the probable projectile trajectory, bone and metal fragments. Dynamic plain radiographs might be applied after the acute trauma to determine spine instability. CT scans are more precise in outlining the osseous anatomy, including the patency of the spine canal and the transverse foramen. MRI is limited because of the usual presence of metal fragments that might contraindicate this type of imaging modality.

Concomitant vascular injuries should be investigated with angiography or a high-resolution CT angiography. ${ }^{9}$ Usually, vertebral artery injury is rare considering it is protected by bone. ${ }^{13}$ A major penetrating trauma, though, can affect the vertebral artery directly, usually causing hemorrhage or indirectly leading to acute or delayed hematoma, pseudo aneurysm, arteriovenous fistula (AVF), or vascular occlusion. Because most of the time this type of lesion is unilateral there is no immediate clinical repercussion and patients with this type of vertebral artery injury are usually asymptomatic due to the vascular harm, as in the patient we present herein.

In our case, CT scan was chosen as it is a faster and more precise exam, also allowing investigation of other segments of the spine. The patient presented a comminuted fracture of the left arch of $\mathrm{C} 1$, the lateral mass, and the transverse foramen. The projectile was embedded at the lateral mass of the atlas and the insertion of the transverse ligament was disrupted. The complete damage of the transverse foramen led to the suspicion of vertebral artery injury. A high resolution CT angiography showed a left vertebral artery occlusion.

Demetriades et al and Syre et al both advocate that surgical exploration of the cervical region is not mandatory. The indications of surgery include spinal instability, as in our case, an expanding hematoma, spinal cord decompression or debridement to prevent or treat infection. ${ }^{1,6}$ It is important to keep in mind that, although such patients might not require immediate surgery, late complications may occur, such as neurological deficits, spinal instability, and osteomyelitis.

Our patient had no neurological or hemodynamic symptoms. Surgical treatment was indicated, considering the cervical spine instability and the patients persistent complain of pain. He was submitted to an atlanto-occipital arthrodesis.

The literature describes patients with gunshot wounds to the cervical spine that developed different types of injuries, from a cervical vertebrae fracture without instability or other tissue damage and submitted to conservative treatment, to an AVF involving the vertebral artery and the paraspinous venous complex presenting with activity induced syncope and treated with endovascular embolization. In the cases that an instable fracture of a cervical vertebrae was detected, a cervical spine arthrodesis including at least two levels below the injury was also the method of choice to stabilize the spine. ${ }^{1,5}$

\section{Conclusion}

Although unusual, it is important to highlight this type of injury considering that civilian gunshot wounds are becoming more frequent due to the increasing incidence of urban violence in modern society. Besides clinical presentation, the investigation must include CT scans, angiography, or angioCT scan. The management will take into consideration the symptoms, the presence or absence of spine instability, and vascular injuries.

\section{Conflict of Interest}

The authors report no conflicts of interest.

\section{References}

1 Syre P III, Rodriguez-Cruz L, Desai R, et al. Civilian gunshot wounds to the atlantoaxial spine: a report of 10 cases treated using a multidisciplinary approach. J Neurosurg Spine 2013;19(6):759-766

2 Kupcha PC, An HS, Cotler JM. Gunshot wounds to the cervical spine. Spine 1990;15(10):1058-1063

3 Mangiardi JR, Alleva M, Dynia R, Zubowski R. Transoral removal of missile fragments from the $\mathrm{C} 1-\mathrm{C} 2$ area: report of four cases. Neurosurgery 1988;23(2):254-257

4 Maniker AH, Gropper MR, Hunt CD. Transoral gunshot wounds to the atlanto-axial complex: report of five cases. J Trauma 1994; 37(5):858-861

5 Dalgic A, Okay O, Nacar O, Daglioglu E, Pasaoglu L, Belen D. Vertebral artery insult at the transverse foramina by gun shot wounds: report of two cases. Turk Neurosurg 2009;19(4): 413-416

6 Demetriades D, Theodorou D, Asensio J, et al. Management options in vertebral artery injuries. Br J Surg 1996;83(1):83-86

7 Ramasamy A, Midwinter M, Mahoney P, Clasper J. Learning the lessons from conflict: pre-hospital cervical spine stabilisation following ballistic neck trauma. Injury 2009;40(12):1342-1345

8 Rostomily RC, Newell DW, Grady MS, Wallace S, Nicholls S, Winn HR. Gunshot wounds of the internal carotid artery at the skull base: management with vein bypass grafts and a review of the literature. J Trauma 1997;42(1):123-132

9 van Deurzen DFP, van As AB, Verleisdonk EJMM. Is routine angiography necessary in patients with a gunshot wound to the neck? A retrospective analysis. Eur J Trauma 2002;28:90-94

10 von See C, Stuehmer A, Gellrich NC, Blum KS, Bormann KH, Rücker $\mathrm{M}$. Wound ballistics of injuries caused by handguns with different types of projectiles. Mil Med 2009;174(7):757-761

11 O'Shaughnessy BA, Bendok BR, Parkinson RJ, Shaibani A, Batjer HH. Transarterial coil embolization of a high-flow vertebrojugular fistula due to penetrating craniocervical trauma: case report. Surg Neurol 2005;64(4):335-340, discussion 340

12 Bono CM, Heary RF. Gunshot wounds to the spine. Spine J 2004; 4(2):230-240

13 Jean WC, Barrett MD, Rockswold G, Bergman TA. Gunshot wound to the head resulting in a vertebral artery pseudoaneurysm at the base of the skull. J Trauma 2001;50(1):126-128 